\title{
Pendidikan Multikultural Dan Pendekatan Quantum Dalam Pembelajaran
}

Oleh

\author{
Rahmathias Jusuf ${ }^{1}$ \\ Email: rahmathiasjusuf@gmail.com
}

\begin{abstract}
Pendidikan memberikan ruang pada budaya untuk mengembangkan dan melestarikan serta memperjelas proposisi esensialnya sebagai bagian yang melekat pada masyarakat. Proses saling mempengaruhi antar satu budaya dengan budaya lain semakin intens dan cepat, baik budaya itu bersifat positif ataupun negatif. Pikiran dan budaya tidak dapat dipisahkan dan saling konstitutif. Relevansi konsep dasar untuk mengkonstruksi pendidikan multikultural dengan pendekatan quantum dalam pembelajaran, proposisi idealnya pada neurolinguistik program dalam pembelajaran. Program ini meneliti hubungan antara bahasa dan perilaku yang dapat digunakan untuk menciptakan jalinan pengertian antara pendidik dan peserta didik. Pendidik mengetahui bagaimana menggunakan bahasa yang positif untuk meningkatkan tindakan-tindakan positif yang merupakan faktor penting untuk merangsang otak. Pikiran dan budaya tidak dapat dipisahkan dan saling konstitutif, studi tentang bagaimana psikologis dan kecenderungan perilaku berakar dalam budaya mempengaruhi penanaman nilai multikultural dalam pembelajaran yang dapat dipahami oleh peserta didik, jika pendekatan quantum memberi penekanan teori pada konsep psikologi melalui kajian neurolinguistik maka bahasa sebagai simbol atau identitas budaya adalah pendukung utama kontruksi pendidikan multikultural.
\end{abstract}

\section{Pendahuluan}

Pendidikan multikultural merupakan proses pengembangan seluruh potensi manusia yang menghargai pluralitas ${ }^{2}$ dan heterogenitas sebagai konsekuensi keragaman budaya, suku, agama, ekonomi, sosial dan politik. Sebagai salah satu negara multikultural terbesar di dunia sudah seharusnya Indonesia mengembangkan pendidikan multikultural sebagai salah satu alternatif Manado.

${ }^{1}$ Penulis adalah Mahasiswa Program Pasca Sarjana Institut Agama Islam Negeri (IAIN)

${ }^{2}$ Pluralitas merupakan realitas yang tidak mungkin diingkari, yaitu suatu hakikat perbedaan dan keragaman yang muncul semata karena diciptakan oleh Allah SWT. Pluralitas yang menyangkut agama adalah toleransi beragama, yang berarti pengakuan akan eksistensi agamaagama lain yang berbeda, beragama dengan seluruh karakteristik dan kekhususannya serta menerima yang lain beserta haknya untuk berbeda dalam beragama dan berkeyakinan. Lihat Anis Malik Thoha, Tren Pluralisme Agama: Tinjauan Kritis, (Jakarta: Perspektif: 2005), h. 206 
proantisipasi konflik sosial budaya yang sering kali terjadi di Indonesia. ${ }^{3}$ Realitas multikultural yang ada di Indonesia merupakan kekayaan dan kekuatan budaya

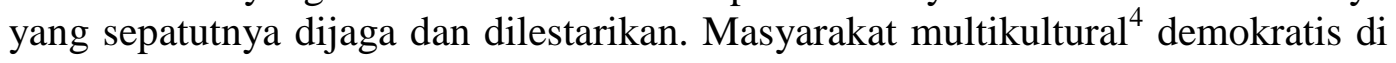
Indonesia yang sehat tidak bisa dibangun secara taken for granted atau trial and error, sebaliknya harus diupayakan secara sistematis, programatis, integrated dan berkesinambungan. Untuk itu, pendidikan multikultural di Indonesia harus mengembangkan model pembelajaran yang mengarah pada beberapa kompetensi dasar yang harus dimiliki warga negara yakni. Pertama, mengembangkan kompetensi akademik standar dan dasar (standar and basic academic skills) tentang nilai persatuan dan kesatuan, demokrasi, keadilan, kebebasan, persamaan derajat atau saling menghargai dalam beraneka jenis keberagaman. Kedua, mengembangkan kompetensi sosial agar dapat menumbuhkan pemahaman yang lebih baik (a better understanding) tentang latar belakang budaya dan agama sendiri dan juga budaya dan agama lain dalam masyarakat. Ketiga, mengembangkan kompetensi akademik untuk menganalisis dan membuat

\footnotetext{
${ }^{3}$ Akar pendidikan multikultural berasal dari perhatian seorang pakar pendidikan Amerika Serikat Prudence Crandall (18-3-1890) yang secara intensif menyebarkan pandangan tentang arti penting latar belakang peserta didik, baik ditinjau dari aspek budaya, etnis, dan agamanya. Pendidikan yang memperhatikan secara sungguh-sungguh latar belakang peserta didik merupakan cikal bakal bagi munculnya pendidikan multikultural. Lihat Abudin Nata, Ilmu Pendidikan Islam Dengan Pendekatan Multidisipliner (Jakarta: Raja Grafindo Persada, 2009), h. 21 pembicaraan mngenai isu-isu multikultural dalam ranah pendidikan formal dimulai pada tahun 1990 Lihat terjemahan buku Thomas J La Belle \& Christoper R. Ward, Multiculturalism and Education: Diversity and Its Impact on Schools and Society, (United States: State of University of New York press, 1994), h. 29. Indonesia adalah salah satu negara multikultural terbesar didunia Lihat Ainul Yaqin, Pendidikan Multikultural Cross-cultural Understanding untuk Demokrasi dan Keadilan (Yogyakarta: Pilar Media, 2005), h. 3 Kekayaan dan keanekaragaman agama, etnik dan kebudayaan, ibarat pisau bermata dua. Di satu sisi kekayaan ini merupakan khazanah yang patut dipelihara dan memberikan nuansa dan dinamika bagi bangsa, dan dapat pula merupakan titik pangkal perselisihan, konflik vertikal dan horizontal. Krisis multidimensi yang berawal sejak pertengahan 1997 dan ditandai dengan kehancuran perekonomian nasional, sulit dijelaskan secara mono-kausal. Cermati Zakiyuddin Baidhawy, Pendidikan Agama Berwawasan Multikultural, (Jakarta: PT.Gelora Aksara Pratama, 2005). h. 21. Hal terkait, Nurcholish Madjid mendefinisikan budaya Indonesia atau keindonesiaan, tidak lain adalah hasil interaksi yang kaya (resourcefull) dan dinamis antarpelaku budaya yang beranekaragam itu dalam suatu melting pot yang efektif Nurcholish Madjid, “Asas-Asas Pluralisme dan Toleransi Dalam Masyarakat Madani, dalam Abuddin Nata, dkk (ed), Problematika Politik Islam di Indonesia, Jakarta: UIN Jakarta Press, 2002, h. 3.
}

${ }^{4}$ Masyarakat multikultural dibentuk melalui proses asimilasi. Interaksi masyarakat berbudaya mengakibatkan terjadinya penetrasi budaya. Penetrasi kebudayaan adalah masuknya pengaruh suatu kebudayaan ke kebudayaan lainnya. Penetrasi budaya secara damai diantaranya terjadi melalui proses Asimilasi budaya (bercampurnya dua kebudayaan sehingga membentuk kebudayaan baru) Lihat Ferdian Tonny Nasdian, Sosiologi Umum, h. 55 Menurut Ki Supriyoko, kontak budaya akan menghasilkan dua kemungkinan, yaitu: Pertama, pertemuan antar budaya tanpa membuahkan nilai-nilai baru yang bermakna, disebut asimilasi, dan Kedua, pertemuan antar budaya yang membuahkan nilai-nilai yang lebih bermakna, disebut akulturasi. Proses asimilasi dan akulturasi hasil kontak budaya pasti terjadi dan keduanya akan memberikan dampak positif dan negative. Lihat juga Ki Supriyoko, Pendidikan Nasional Sebagai Pengiring Kebudayaan Nasional, Materi Perkuliahan Pascasarjana UIN Sunan Kalijaga, Tahun 2007 
keputusan yang cerdas (intelegent dicisions) tentang isu-isu dan masalah keseharian (real life problems) melalui sebuah proses demokratis atau penyelidikan dialogis. Keempat, membantu mengkonseptualisasi dan mengaspirasikan konstruksi masyarakat yang lebih baik, demokratis, egaliter, tanpa ada diskriminasi, penindasan, dan pelanggaran terhadap nilai asasi universal. ${ }^{5}$

Pergeseran nilai-nilai budaya dalam masyarakat menjadi problem yang harus segera dikritisi dalam dunia akademik. Pembahasan konsep-konsep, karakter maupun nilai-nilai kebudayaan telah mancapai tahap akhir dalam peradaban. Pendidikan menjadi wadah pembenaran, penanaman nilai bahkan problem solving dalam setiap dinamika sosial budaya masyarakat adalah wacana penting yang seyogianya diaktualisasikan oleh seluruh lapisan masyarakat budaya. ${ }^{6}$ Dalam hal ini, penulis mengasumsikan bahwa pendidikan mengambil peran penting dalam pengelolaan sistem kemasyarakatan termasuk kendali sosial budaya masyarakat. Konsep tentang multikultural melalui penelusuran para ahli manunjukan bahwa multikulturalisme memberikan ruang kepada masyarakat dengan keberagamannya mewujudkan nilai-nilai budaya masyarakat pada tatanan demokratis inklusif dengan tetap mempertahankan simbol-simbol kearifan lokal yang ada. Penerapan nilai-nilai budaya akan lebih terarah melalui proses pendidikan di sekolah. ${ }^{7}$ Berdasarkan hal tersebut maka penulis mengkonstruksi pendekatan quantum dalam pembelajaran untuk menanamkan nilai-nilai multikultural pada peserta didik.

${ }^{5}$ Yuli Adhani, Konsep Pendidikan Multikultural Sebagai Sarana Alternatif Pencegahan Konflik, Ditulis dalam Jurnal Sosio Didaktika: Vol. 1, No. 1 Mei 2014, h. 112

${ }^{6}$ Hilda Hernandez mengartikan pendidikan multikultural sebagai perspektif yang mengakui realitas politik, sosial, dan ekonomi yang dialami oleh masing-masing individu dalam pertemuan manusia yang kompleks dan beragam secara kultur, dan merefleksikan pentingnya budaya, ras, seksualitas dan gender, etnisitas, agama, status sosial, ekonomi, politik dan pengecualian dalam proses pendidikan. Pandangan tersebut dapat dimaknai bahwa ruang pendidikan multikultural sebagai media transformasi ilmu pengetahuan (transfer of knowledge) hendaknya mampu memberikan nilai-nilai multikulturalisme dengan saling menghargai dan menghormati atas realitas yang beragam (pluralis), baik latar belakang maupun basis sosial budaya yang melingkupinya. Cermati Hilda Hernandez, Multicultural Education: A Teacher Guide to Linking Context, Process, and Content. New Jersey \& Ohio: Prentice Hall, 1989, h. 6 Lihat juga Alo Liliweri, Sosiologi \& Komunikasi Organisasi, (Jakarta: Bumi Aksara, 2014), h. 289 apresiasi di antara orang-orang yang berbeda kebudayaan.

${ }^{7}$ Pendidikan sebagai basis nilai moral-spiritual harus dapat menjadi solusi terhadap munculnya dampak globalisasi. Pendidikan memberikan ruang pada budaya untuk mengembangkan dan melestarikan serta memperjelas proposisi esensialnya sebagai bagian yang melekat pada masyarakat itu sendiri. Masyarakat dalam interaksi sosial pada umumnya dipengaruhi oleh status sosial budayanya. Sehingga budaya secara utuh membentuk sistem tatanan hubungan antar masyarakat, dan hal demikian dimulai dari proses pendidikan. 


\section{Paradigma dan Tantangan Globalisasi}

Pendidikan akan selalu dihadapkan dengan beberapa tantangan globalisasi ${ }^{8}$ yang harus disikapi oleh pendidik dengan mengedepankan profesionalisme. Paradigma yang harus diperhatikan oleh pendidik dewasa ini diantaranya, Pertama, pendidik tidak terjebak pada rutinitas belaka tetapi selalu mengembangkan dan memberdayakan diri secara terus menerus untuk meningkatkan kualifikasi dan kompetensinya. Kedua, pendidik mampu menyusun dan melaksanakan strategi dan model pembelajaran yang aktif, kreatif, inofatif, efektif dan menyenangkan yang dapat memotivasi peserta didik. Ketiga, dominasi pendidik dalam pembelajaran dikurangi, sehingga memberikan kesempatan kepada peserta didik untuk lebih berani, mandiri dan kreatif dalam proses belajar mengajar. Keempat, pendidik mampu memodifikasi dan memperkaya bahan pembelajaran sehingga peserta didik mendapatkan sumber belajar yang lebih bervariasi. $^{9}$

Pendidikan yang berbasis multikultural harus dapat memberi pemahaman tentang keberadaan masyarakat plural yang membutuhkan ikatan-ikatan keadaban, yang berupa pergaulan antar budaya yang diikat oleh suatu peradaban. Tentu saja ikatan tersebut dibangun oleh nilai-nilai universal kemanusiaan, yang ditransfer kepada masyarakat agar menemukan tujuan kepemilikan dan kelanggengan. Kepemilikan nilai-nilai universal itu dapat melembaga dalam masyarakat untuk mewujudkan budaya luhur, sehingga tercipta masyarakat yang aman, tertib, berwibawa, dan bermartabat. Untuk dapat memahami pendidikan multikultural, perlu dipahami karakteristik budaya dan wilayah budaya. Pemahaman terhadap karakteristik budaya antara lain meliputi budaya sebagai suatu hal yang general sekaligus sebagai suatu yang spesifik. Di samping itu budaya juga merupakan sesuatu yang dapat dipelajari, sebagai suatu simbol, sebagai milik bersama, sebagai atribut individu, budaya juga sebagai suatu model, dan budaya sebagai suatu yang bersifat adaptif. Kesadaran multikultural juga didorong oleh perkembangan global (arus globalisasi) yang berdampak pada perjumpaan lintas budaya dan agama yang berlangsung amat intens. ${ }^{10}$

Pendidikan sebagai sebuah proses pengembangan sumber daya manusia agar memiliki kemampuan sosial dengan perkembangan individu yang optimal, memberikan relasi yang kuat antara individu dengan masyarakat dan lingkungan budaya sekitarnya. Pendidikan merupakan proses memanusiakan manusia, sehingga manusia diharapkan mampu memahami dirinya, orang lain, alam dan lingkungan budayanya. Atas dasar inilah, pendidikan tidak boleh dilepaskan dari

\footnotetext{
${ }^{8}$ Interpretasinya menunjukan Proses saling mempengaruhi antar satu budaya dengan budaya lain yang semakin intens dan cepat, baik budaya itu bersifat positif ataupun negatif.

${ }^{9}$ Kunandar, Guru Profesional Implementasi KTSP dan Sukses Sertifikasi Guru, (Jakarta: Rajawali Press, 2007), h. 42-43

${ }^{10}$ Komaruddin Hidayat, "Merawat Keragaman Budaya" dalam Tonny D. Widiastono (ed.), Pendidikan Manusia Indonesia (Jakarta: Buku Kompas, 2004), h. 89
} 
budaya yang melingkupinya sebagai kuensekuensi dari tujuan pendidikan yaitu, mengasah rasa, karsa dan karya. ${ }^{11}$ Pendidikan demokratis dan pendidikan pluralismultikultural merupakan sebuah rangkaian, masing-masing saling bergantung dan saling mempengaruhi. Oleh karena itu, membangun pendidikan yang berparadigma pluralais-multikultural merupakan kebutuhan yang tidak bisa ditunda lagi. Dengan paradigma semacam ini, pendidikan diharapkan membentuk peserta didik yang memiliki cakrawala pandang yang luas, menghargai perbedaan, penuh toleransi, dan penghargaan terhadap segala sesuatu bentuk perbedaan. ${ }^{12}$

\section{Pendekatan Quantum dalam Pembelajaran}

Dalam konteks kompetensi metodologis, pendidik harus memahami dan memiliki kemampuan dalam menerapkan pendekatan, metode dan strategi pembelajaran yang relevan dengan objek (peserta didik), efektif dan menyenangkan atau sesuai dengan prinsip pembelajaran aktif, inovatif, kreatif, efektif dan menyenangkan (PAIKEM). PAIKEM adalah sebuah pembelajaran yang memungkinkan peserta didik untuk mengerjakan kegiatan yang beragam dalam rangka mengembangkan keterampilan dan pemahamannya, dengan penekanan peserta didik belajar sambil bekerja, sementara pendidik menggunakan berbagai sumber dan alat bantu belajar (termasuk pemanfaatan lingkungan), supaya pembelajaran lebih menarik, menyenangkan dan efektif. ${ }^{13}$

Strategi merupakan pendekatan yang dipakai oleh pendidik dalam memanipulasi informasi, memilih sumber-sumber dan menentukan peranan peserta didik dalam proses pembelajaran. ${ }^{14}$ Seorang pendidik dapat mengajar

${ }^{11}$ Zainal Abidin, Pendidikan Agama Islam Dalam Perspektif Multikulturalisme, (Jakarta: Balai Litbang Agama, 2009), h. 139

${ }^{12}$ Ngainun Naim, Pendidikan Multikultural Konsep dan Aplikasi, (Jogjakarta: Ar-Ruz, 2008), h. 73

${ }^{13}$ Dewi Laksmi dan Masitoh., Strategi Pembelajaran, (Direktorat Jenderal Pendidikan Islam Departemen Agama Republik Indonesia., Jakarta Pusat 2009), h. 56. PAIKEM merupakan sebuah model pembelajaran kontekstual yang melibatkan paling sedikit empat prinsip utama dalam proses pembelajarannya. Pertama; proses Interaksi (peserta didik berinteraksi secara aktif dengan pendidik, rekan peserta didik, multi-media, referensi, lingkungan dsb). Kedua; proses Komunikasi (peserta didik mengkomunikasikan pengalaman belajar mereka dengan pendidik dan rekan peserta didik lain melalui cerita, dialog atau melalui simulasi role-play). Ketiga; proses Refleksi, (peserta didik memikirkan kembali tentang kebermaknaan tentang hal-hal yang telah mereka pelajari, dan apa yang mereka telah lakukan). Keempat; proses Eksplorasi (peserta didik mengalami langsung dengan melibatkan semua indera mereka melalui pengamatan, percobaan, penyelidikan dan/atau wawancara). Telaah Bafadal, Ibrahim, Manajemen Peningkatan Mutu Sekolah Dasar: dari Sentralisasi Menuju Desentralisasi, (Jakarta: Bumi Aksara, 2003), h. 21

\footnotetext{
${ }^{14}$ Subari, Supervisi Pendidikan Dalam Rangka Perbaikan Situasi Mengajar, (Jakarta: Bumi Aksara, 1994), h. 73 mendukung definisi di atas, Lihat Ad Rooijakkers, Mengajar Dengan Sukses, (Jakarta: Grasindo, 1991), h. 1 dalam proses pembelajaran, pendidik harus memiliki strategi agar peserta didik dapat belajar secara efektif dan efisien, mengena pada tujuan yang diharapkan. Mengajar berarti menyampaikan atau menularkan pengetahuan atau pandangan. Strategi menurut Kemp merupakan suatu kegiatan pembelajaran yang harus dilakukan pendidik dan peserta didik agar tujuan pembelajaran dapat dicapai secara efektif dan efisien. Lihat Rusman, Model-Model
} 
berhitung menurut cara yang sama dari tahun ketahun yakni dengan melatih hitungan-hitungan dalam buku. Pada kesempatan yang lain, pendidik menghubungkan pelajaran berhitung dengan pengalaman peserta didik dalam kehidupannya, hasilmya autentik dan tahan lama. Banyak pendidik memberikan pelajaran untuk keperluan ujian yang segera akan dilupakan oleh peserta didik. Dalam suatu penyelidikan ternyata bahwa, pelajaran menghitung menimbulkan frustasi pada peserta didik, pelajaran itu justru merusak pribadi peserta didik. ${ }^{15}$ Kompetensi pedagogik merupakan kemampuan yang harus dimiliki pendidik dalam pengelolaan peserta didik, diantaranya pendidik memahami potensi dan keberagaman peserta didik, sehingga dapat didesain strategi pembelajaran yang sesuai dengan keunikan masing-masing peserta didik. ${ }^{16}$

Pelaksanaan PAIKEM harus memperhatikan bakat, minat dan modalitas belajar peserta didik, dan bukan semata potensi akademiknya. Dalam pendekatan pembelajaran Quantum ${ }^{17}$ (Quantum Learning) ada tiga macam modalitas peserta didik, yaitu modalitas visual, auditorial dan kinestetik. Dengan modalitas visual dimaksudkan bahwa kekuatan belajar peserta didik terletak pada indera 'mata' (membaca teks, grafik atau dengan melihat suatu peristiwa), kekuatan auditorial terletak pada indera 'pendengaran' (mendengar dan menyimak penjelasan atau cerita), dan kekuatan kinestetik terletak pada 'perabaan' (seperti menunjuk, menyentuh atau melakukan). Jadi, dengan memahami kecenderungan potensi modalitas peserta didik tersebut, maka seorang pendidik harus mampu merancang media, metoda/atau materi pembelajaran kontekstual yang relevan dengan kecenderungan potensi atau modalitas belajar peserta didik. Quantum Learning merupakan terobosan baru berdasarkan prinsip pembelajaran aktif, inovatif, kreatif, efektif dan menyenangkan (PAIKEM). Pendidik sering mengelompokan quantum learning sebagai salah satu strategi atau juga metode pembelajaran,

Pembelajaran Mengembangkan Profesionalisme Guru, (Jakarta: Raja Grafindo, 2012), h. 18, Senada dengan pendapat Kemp, Dick dan Cary juga menyebutkan bahwa strategi pembelajaran adalah suatu perangkat materi dan prosedur pembelajaran yang digunakan bersama-sama untuk menimbulkan hasil belajar pada peserta didik. Upaya mengimplementasikan rencana pembelajaran yang telah disusun dalam kegiatan nyata agar tujuan dapat tercapai, maka diperlukan suatu metode yang digunakan untuk merealisasikan hal tersebut. Dalam hal ini dapat dikatakan bahwa strategi adalah a plan of operation achievement something, sedangkan metode adalah a way in achievement something. Cermati Suparlan, pembelajaran aktif kreatif, efektif dan menyenangkan (PAKEM) (Bandung: PT Genesindo, 2009), h. 5 pada penjelasan lainnya terkait pembahasan, model-model pembelajaran biasa disusun berdasarkan prinsip-prinsip teori pengetahuan.

${ }^{15}$ J. Mursel, Mengajar dengan Sukses, (Jakarta: Bumi Aksara, 2002), h. 5

${ }^{16}$ Saiful Sagala, Kemampuan Profesional Guru dan Tenaga Kependidikan, (Bandung: ALFABETA, 2009) h. 31

${ }^{17}$ Istilah Quantum dalam Kamus Besar Bahasa Indonesia tertulis Kuantum yang berarti banyaknya (jumlah) sesuatu atau bagian dari energy yang tidak dapat dibagi lagi. Lihat Departemen Pendidikan dan Kebudayaan, Kamus Besar Bahasa Indonesia, (Jakarta: Balai Pustaka, 1995), h. 232. Menurut Jalaluddin Rahmat, kata Quantum berarti loncatan Lihat Jalaluddin Rahmat, Catatan Kang Jalal Visi Media, Politik, dan Pendidikan, (Bandung: Remaja Rosda Karya, 1997), h. 350 
namun berdasarkan pengertian dan beberapa istilah yang telah penulis jelaskan sebelumnya, penulis menyimpulkan bahwa quantum learning merupakan satu konsep pembelajaran yang disusun dari berbagai teori pendidikan, psikologi, sosial, dan beberapan teori lainnya. Penekanan teori lebih pada konsep psikologi. Teori ini berakar dari upaya Georgi Lozanov, pendidik berkebangsaan Bulgaria, yang bereksperimen dengan apa yang disebut sebagai Sugestopedia, prinsipnya adalah sugesti dapat dan pasti mempengaruhi hasil dan kondisi belajar dan setiap detail prosesnya memberikan sugesti positif dan negative. Beberapa teknik yang digunakan untuk memberikan sugesti yang positif adalah memberikan posisi nyaman kepada peserta didik di kelas, memasang musik latar dalam pembelajaran, meningkatkan partisipasi individu, menggunakan poster-poster untuk memberikan kesan agar informasi mudah disampaikan dan diterima oleh peserta didik dan menggunakan pendidik yang terlatih dalam bidang seni dan pengajaran sugestif. ${ }^{18}$

Quantum learning mencakup aspek-aspek penting dalam program neurolinguistik, yaitu suatu penelitian tentang bagaimana otak mengatur informasi. ${ }^{19}$ Para pendidik mendefinisikan quantum learning sebagai interaksiinteraksi yang mengubah energy menjadi cahaya. Semua kehidupan adalah energy. Quantum learning menggabungkan sugestologi, teknik percepatan belajar dan neurolinguistik dengan teori keyakinan, serta model pendidik sendiri, termasuk diantaranya konsep kunci dari berbagai teori dan strategi belajar lainnya, seperti teori otak kiri dan kanan, pilihan modalitas visual, audio dan kinestetik, teori kecerdasan ganda, pendidikan holistik, belajar berdasarkan pengalaman, belajar dengan simbol, dan simulasi dalam pembelajaran. ${ }^{20}$

\footnotetext{
${ }^{18}$ Bobbi Deporter, Quantum Learning Membiasakan Belajar Nyaman Dan Menyenangkan, (Bandung: Mizan, 2011), h. 14 Cetak miring dan tebal ditambahkan penulis. Pembelajaran quantum learning menekankan konsep psikologis untuk memetakan kondisi peserta didik. Hal ini untuk mengetahui hal-hal yang disukai dan tidak disukai oleh peserta didik, sehingga pendidik dapat dengan mudah memilih pendekatan atau strategi pembelajaran yang baik untuk digunakan dalam pembelajaran. Istilah lain yang hampir sama dengan sugestology adalah percepatan belajar. (accelerated Learning). Cara ini menyatukan hal-hal sekilas nampak akan tetapi tidak mempunyai persamaan misalnya, hiburan, permainan, warna, cara berfikir, kebugaran fisik, dan kesehatan emosional, namun semua unsur ini ternyata dapat bekerjasama dan menghasilkan pengalaman belajar yang efektif.

${ }^{19}$ Program ini meneliti hubungan antara bahasa dan perilaku yang dapat digunakan untuk menciptakan jalinan pengertian antara pendidik dan peserta didik. Pendidik mengetahui bagaimana menggunakan bahasa yang positif untuk meningkatkan tindakan-tindakan positif yang merupakan faktor penting untuk merangsang otak. Neurolinguistik adalah salah satu bidang kajian interdisipliner dalam ilmu linguistik dan ilmu kedokteran yang mengkaji hubungan antara otak manusia dengan bahasa.

${ }^{20}$ Penggunaan bahasa yang tepat dalam memberikan informasi kepada peserta didik dapat membantu peserta didik dalam memahami materi pembelajaran. Keragaman bahasa sebagai simbol budaya juga mempengaruhi pemetaan karakter, cara berfikir dan tingkah laku peserta didik di dalam kelas.
} 
Pendekatan Quantum Teaching diantaranya dikembangkan berdasarkan teori Accelerated Learning dan teori Neurolinguistik ${ }^{21}$ yang dijelaskan pada bahasan sebelumnya. Quantum Teaching bersandar pada konsep ini: "Bawalah Dunia Mereka ke Dunia Kita dan Amalkan Dunia Kita ke Dunia Mereka", Maksudnya yaitu mengingatkan pendidik pada pentingnya memasuki dunia peserta didik sebagai langkah pertama. Untuk mendapatkan hak mengajar, pertama-tama sebagai pendidik harus membangun jembatan autentik memasuki kehidupan peserta didik. Sertifikat mengajar atau dokumen yang mengizinkan mengajar atau melatih hanya berarti bahwa memiliki wewenang untuk mengajar. Hal ini tidak berarti bahwa mempunyai hak mengajar. Mengajar adalah hak yang harus diraih dan diberikan oleh peserta didik, bukan oleh Departemen Pendidikan. Belajar dari segala definisinya adalah kegiatan full contact. Dengan kata lain belajar melibatkan semua aspek kepribadian manusia, pikiran, perasaan dan bahasa tubuh disamping pengetahuan, sikap dan keyakinan sebelumnya, serta persepsi masa mendatang. Dengan demikian, karena belajar berurusan dengan orang secara keseluruhan, hak untuk memudahkan belajar tersebut harus diberikan oleh pelajar dan diraih oleh pendidik. ${ }^{22}$

Ada beberapa prinsip Quantum Teaching, yaitu: ${ }^{23}$

1. Segalanya berbicara, lingkungan kelas, bahasa tubuh dan bahan pelajaran semuanya menyampaikan pesan tentang belajar. ${ }^{24}$

2. Segalanya bertujuan, peserta didik diberi tahu apa tujuan merekan mempelajari materi yang pendidik ajarkan.

3. Pengalaman sebelum pemberian nama, otak berkembang pesat dengan adanya rangsangan kompleks, yang akan menggerakkan rasa ingin tahu. Oleh karena itu, proses belajar paling baik terjadi ketika peserta didik telah mengalami informasi sebelum mereka memperoleh nama untuk apa yang mereka pelajari.

4. Akui setiap usaha, menghargai usaha peserta didik sekecil apapun. Belajar mengandung resiko. Belajar berarti melangkah keluar dari kenyamanan. Pada saat peserta didik mengambil langkah ini, mereka patut mendapat pengakuan atas kecakapan dan kepercayaan diri mereka.

\footnotetext{
${ }^{21}$ Kata Neuro adalah saraf otak, Linguistik adalah cara berbahasa, baik verbal maupun non verbal yang dapat mempengaruhi sistem pikiran, perasaan dan perilaku. Lihat Amir Faisal, Menyiapkan Anak Jadi Juara, (Jakarta: Elek Media Komputindo Gramedia, 2008), h. 95

${ }^{22}$ Bobbi Deporter, Quantum Teaching: Mempraktikkan Quantum Learning Di Ruang-Ruang Kelas, (Bandung: Mizan, 2010), h. 35

${ }^{23}$ Bobbi Deporter, Quantum Teaching: Mempraktikkan Quantum Learning Di Ruang-Ruang Kelas, h. 37

${ }^{24}$ Lingkungan sosial dan suasana kelas adalah penentu psikologis utama yang mempengaruhi belajar akademis. Kajian psikologi pendidikan terkait prinsip-prinsip, teknik-teknik psikologi dalam pendidikan. Crow mengemukakan ruang lingkup psikologi dalam pendidikan diantaranya: hunbungan antara prosedur-prosedur mengajar dengan hasil belajar. Lihat dan telaah M. Ngalim Purwanto, Psikologi Pendidikan, (Bandung: Remaja Rosdakarya, 2013), h. 10
} 
5. Jika layak dipelajari, layak pula dirayakan, pendidik harus memberi pujian pada peserta didik yang terlibat aktif pada pelajaran. Misalnya saja dengan memberi tepuk tangan, berkata: bagus dan lain-lain.

\section{Konstruksi Pendidikan Multikultural dengan Pendekatan Quantum}

Pendidikan multikultural kian mendesak untuk dilaksanakan di sekolah. Dengan pendidikan multikultural, sekolah menjadi lahan untuk menghapus prasangka, dan sekaligus untuk melatih dan membangun karakter siswa agar mampu bersikap demokratis, humanis dan pluralis. Ada dua hal yang perlu dilakukan dalam pembangunan pendidikan multikultural di sekolah, yaitu; pertama, melakukan dialog dengan menempatkan setiap peradaban dan kebudayaan yang ada pada posisi sejajar. Kedua, mengembangkan toleransi untuk memberikan kesempatan masing-masing kebudayaan saling memahami. Toleransi disini tidak hanya pada tataran konseptual, melainkan juga pada teknik operasionalnya. $^{25}$

Pengembangan perspektif sejarah (etnohistorisitas) yang beragam dari kelompok-kelompok masyarakat, memperkuat kompetensi interkultural dari budaya-budaya yang hidup di masyarakat dengan nilai-nilai inti dari multikultural berupa (demokratis), (humanisme), (pluralisme). Adapun dalam pendidikan multikultural, proses nilai yang ditanamkan berupa cara hidup menghormati, tulus, toleran terhadap keragaman budaya yang hidup di tengah-tengah masyarakat yang plural. Untuk itu lewat pendidikan multikultural sebagai wadah menanamkan kesadaran tentang nilai-nilai multikultural ${ }^{26}$ dan kesadaran bahwa keragaman hidup sebagai suatu kenyataan yang harus dihadapi dan disikapi dengan penuh kearifan, tentu saja, penanaman konsep seperti ini dilakukan dengan tidak mengurangi kemurnian masing-masing agama yang diyakini kebenarannya oleh anak didik. ini yang harus memperoleh penegasan agar tidak terjadi kesalapahaman. ${ }^{27}$ Pendekatan quantum learning yang menggabungkan konsep sugestologi, accelerated learning dan neurolinguistik program dalam pembelajaran sebagai upaya meningkatkan hasil belajar peserta didik yang

${ }^{25}$ Erlan Muliadi, Urgensi Pembelajaran Pendidikan Agama Islam Berbasis Multikultural di Sekolah, Ditulis dalam Jurnal Pendidikan Pendidikan Islam, Fakultas Tarbiyah dan Keguruan UIN Sunan Kalijaga Yogyakarta Volume I, Nomor 1, Juni 2012, h. 6

${ }^{26}$ Nilai merupakan inti dari setiap kebudayaan. Dalam hal ini mencakup nilai moral yang mengatur aturan-aturan dalam kehidupan bersama. Moral itu sendiri mengalami perkembangan yang diawali sejak dini. Perkembangan moral seseorang merupakan hal yang sangat penting bagi perkembangan kepribadian dan sosial anak, untuk itu pendidikan moral sedikit banyak akan berpengaruh pada sikap atau perilaku ketika berinteraksi dengan orang lain Lihat Haditono. S.R. Psikologi Perkembangan Pengantar dalam Berbagai Bagiannya. (Yogyakarta: Gadjah Mada University Press. 2002). h. 168

\footnotetext{
${ }^{27}$ Ngainun Naim dan Achmad Sauqi, Pendidikan Multikultural Konsep dan Amlikasi, (Jogjakarta: Ar-Ruzz Media. 2011) h. 53. Cetak Miring dan Tebal ditambahkan oleh penulis
} 
kemudian dikembangkan pada pendekatan quantum teaching merumuskan beberapa prinsip kunci dalam penerapannya yang sesuai dengan nilai-nilai pendidikan multikultural diantaranya; a) Integritas, bersikap jujur, tulus dan menyeluruh serta menyelaraskan nilai-nilai dengan perilaku. b) Berbicara dengan niat baik, berbicara dengan pengertian positif dan bertanggung jawab untuk komunikasi yang jujur dan lurus. c) Menghindari gosip dan komunikasi yang berbahaya. d) Komitmen, dan bertanggung jawab atas tindakan. e) Bersikap luwes atau fleksibel, bersikap terbuka terhadap perubahan atau pendekatan baru.

Relevansi konsep dasar untuk mengkonstruksi pendidikan multikultural dengan pendekatan quantum baik dengan pendekatan quantum learning maupun pendekatan quantum teaching dalam pembelajaran, proposisi idealnya terletak pada neurolinguistik program dalam pembelajaran. Multikulturalisme di bidang psikologi melengkapi behaviorisme, teori psikodinamik, dan psikologi humanistik. Dalam kursus ini untuk mengeksplorasi topik-topik seperti perbedaan pandangan dunia dan sarana komunikasi, proses akulturasi, stereotip, prasangka, pengembangan identitas budaya dan membangun kompetensi multikultural. Pentingnya kehati-hatian pendidik dalam menggunakan atau memilih bahasa mempengaruhi pola pikir dan perilaku peserta didik. ${ }^{28}$

Neurolinguistik berfokus pada upaya untuk membuat sebuah model neural program yang merupakan rekonstruksi kerja otak dalam memproses kegiatan bicara, mendengar, membaca, menulis, dan berbahasa isyarat. Neurolinguistik lebih berkecimpung dalam memahami kesulitan berbahasa atau gangguan berbahasa, yang mencakup kegiatan berbicara, mendengar, membaca, menulis, dan berbahasa isyarat yang menggangu kemampuan berkomunikasi. Sementara itu, multikulturalisme meletakkan bahasa sebagai faktor utama dalam transformasi budaya. $^{29}$ Ahli bahasa Swiss bernama Saussure berusaha menetapakan dan mengembangkan disiplin ilmu linguistic structural. Sanssure menetapkan linguistik sebagai ilmu pengetahuan dengan pemilihan dan definisi yang akhirnya diketahui oleh siapa saja yang bersentuhan dengan kajian akademis budaya.

\footnotetext{
${ }^{28}$ Pengetahuan tidak dapat dipindahkan begitu saja dari pikiran pendidik ke pikiran peserta didik. Peserta didik harus aktif secara mental membangun struktur pengetahuannya berdasarkan kematangan kognitif yang dimilikinya. Dalam kajian ini, peserta didik bersifat adaptif membuat kaitan antara gagasan dengan informasi baru yang diterima dalam pengkonstruksian secara bermakna. Lihat Iif Khoiru Ahmadi, Konstruksi Pengembangan Pembelajaran Pengaruhnya Terhadap Mekanisme dan Praktik Kurikulum, (Jakarta: Prestasi Pustakaraya, 2010), h. 148 Rorty melihat ilmu pengetahuan sebagai konstruksi sosial-budaya. Selain itu, Proses pendidikan multikultural dipengaruhi oleh konstruksi teori dan cerminan realitas. Lihat Akhyar Yusuf Lubis, Teori dan Metodologi Ilmu Pengetahuan Sosial-Budaya Kontemporer, (Jakarta: Raja Grafindo, 2014), h. 223

${ }^{29}$ Pikiran dan budaya tidak dapat dipisahkan dan saling konstitutif, studi tentang bagaimana psikologis dan kecenderungan perilaku berakar dalam budaya mempengaruhi pendidikan multikultural dalam pembelajaran yang dapat dipahami oleh peserta didik, jika pendekatan quantum memberi penekanan teori pada konsep psikologi melalui kajian neurolinguistik maka bahasa sebagai simbol atau identitas budaya adalah pendukung utama kontruksi pendidikan multikultural dalampembelajaran.
} 
Tujuan linguistik adalah untuk memanfaatkan berbicara dan menulis sebagai caracara dimana struktur yang melatarbelakangi bahasa, objek linguistik, dikonstruksi. Ini artinya bahwa kaidah maupun relasinya dapat dipahami dan digunakan untuk menerangkan penggunaan tertentu atas bahasa manusia. Oleh karena itu, linguistik mencakup kajian language sebagai sebuah sistem atau struktur. Bahasa sebagai sistem seperti halnya budaya hanya bisa dikaji dan dipahami dalam pengertianpengertian relasional. Kajian ini mencakup pencarian dan penelitian sistem kaidah. Jika bahasa dapat dipahami maka sistem-sistem budaya lain juga dapat dipahami, selain itu bahasa menerangkan makna dalam menganalisis berbagai struktur budaya masyarakat. ${ }^{30}$

\section{Penutup}

Pikiran dan budaya tidak dapat dipisahkan dan saling konstitutif, studi tentang bagaimana psikologis dan kecenderungan perilaku berakar dalam budaya mempengaruhi penanaman nilai-nilai multikultural dalam pembelajaran yang dapat dipahami oleh peserta didik, jika pendekatan quantum memberi penekanan teori pada konsep psikologi melalui kajian neurolinguistik atau cara berbahasa, baik verbal maupun non verbal yang dapat mempengaruhi sistem pikiran, perasaan dan perilaku maka bahasa sebagai simbol atau identitas budaya adalah faktor pendukung utama kontruksi pendidikan multikultural. Penguasaan pendekatan quantum (quantum learning dan quantum teaching) mempengaruhi struktur dalam merekonstruksi pola penanaman nilai multikultural pada peserta harus dipahami oleh pendidik.

${ }^{30}$ Dominik Strinati, Popular Culture Pengantar Menuju Teori Budaya Populer, (Yogyakarta: Buku Seru, 2016), h. 109-111 Saussure meletakan dasar linguistik modern. Strukturalisme sebagaimana tersirat berkaitan dengan penyingkapan struktur sebagai aspek pemikiran dan tingkah laku manusia. Lihat Zaprulkhan, Filsafat Ilmu Sebuah Analisis Kontemporer, (Jakarta: Raja Grafindo, 2016), 178 


\section{DAFTAR PUSTAKA}

Abidin, Zainal, Pendidikan Agama Islam Dalam Perspektif Multikulturalisme, Jakarta: Balai Litbang Agama, 2009

Ahmadi, Iif Khoiru, Konstruksi Pengembangan Pembelajaran Pengaruhnya Terhadap Mekanisme dan Praktik Kurikulum, Jakarta: Prestasi Pustakaraya, 2010

Baidhawy, Zakiyuddin, Pendidikan Agama Berwawasan Multikultural, Jakarta: Gelora Aksara Pratama, 2005

Bobbi Deporter, Quantum Teaching: Mempraktikkan Quantum Learning Di Ruang-Ruang Kelas, Bandung: Mizan, 2010

Deporter, Bobbi, Quantum Learning Membiasakan Belajar Nyaman Dan Menyenangkan, Bandung: Mizan, 2011

Faisal, Amir, Menyiapkan Anak Jadi Juara, Jakarta: Elek Media Komputindo Gramedia, 2008

Hernandez, Hilda, Multicultural Education: A Teacher Guide to Linking Context, Process, and Content. New Jersey \& Ohio: Prentice Hall, 1989, h. 6

Hidayat, Komaruddin, "Merawat Keragaman Budaya" dalam Tonny D. Widiastono, Pendidikan Manusia Indonesia, Jakarta: Buku Kompas, 2004

Ibrahim, Bafadal, Manajemen Peningkatan Mutu Sekolah Dasar: dari Sentralisasi Menuju Desentralisasi, Jakarta: Bumi Aksara, 2003

Kamus Besar Bahasa Indonesia, Jakarta: Balai Pustaka, 1995

Kunandar, Guru Profesional Implementasi KTSP dan Sukses Sertifikasi Guru, Jakarta: Rajawali Press, 2007

Laksmi, Dewi, Strategi Pembelajaran, Direktorat Jenderal Pendidikan Islam Departemen Agama Republik Indonesia, Jakarta Pusat 2009

Liliweri, Alo, Sosiologi \& Komunikasi Organisasi, Jakarta: Bumi Aksara, 2014

Lubis, Akhyar Yusuf, Teori dan Metodologi Ilmu Pengetahuan Sosial-Budaya Kontemporer, Jakarta: Raja Grafindo, 2014

Mursel, J, Mengajar dengan Sukses, Jakarta: Bumi Aksara, 2002

Naim, Ngainun, Pendidikan Multikultural Konsep dan Aplikasi, Jogjakarta: ArRuz, 2008 
Naim, Ngainun dan Achmad Sauqi, Pendidikan Multikultural Konsep dan Aplikasi, Jogjakarta: Ar-Ruzz Media. 2011

Nata, Abuddin, Ilmu Pendidikan Islam Dengan Pendekatan Multidisipliner, Jakarta: Raja Grafindo Persada, 2009

Press, 2002

Purwanto, M. Ngalim, Psikologi Pendidikan, Bandung: Remaja Rosdakarya, 2013

Rahmat, Jalaluddin, Catatan Kang Jalal Visi Media, Politik, dan Pendidikan, Bandung: Remaja Rosda Karya, 1997

Rooijakkers, Ad, Mengajar Dengan Sukses, Jakarta: Grasindo, 1991

Rusman, Model-Model Pembelajaran Mengembangkan Profesionalisme Guru, Jakarta: Raja Grafindo, 2012

S.R. Haditono, Psikologi Perkembangan Pengantar dalam Berbagai Bagiannya., Yogyakarta: Gadjah Mada University Press. 2002

Sagala, Saiful, Kemampuan Profesional Guru dan Tenaga Kependidikan, Bandung: ALFABETA, 2009

Strinati, Dominik, Popular Culture Pengantar Menuju Teori Budaya Populer, Yogyakarta: Buku Seru, 2016

Subari, Supervisi Pendidikan Dalam Rangka Perbaikan Situasi Mengajar, Jakarta: Bumi Aksara, 1994

Suparlan, pembelajaran aktif kreatif, efektif dan menyenangkan (PAKEM), Bandung: Genesindo, 2009

Supriyoko, Pendidikan Nasional Sebagai Pengiring Kebudayaan Nasional, Materi Perkuliahan Pascasarjana UIN Sunan Kalijaga, Tahun 2007

Thoha, Anis Malik, Tren Pluralisme Agama: Tinjauan Kritis, Jakarta: Perspektif, 2005

Thomas J La Belle \& Christoper R. Ward, Multiculturalism and Education: Diversity and Its Impact on Schools and Society, United States: State of University of New York press, 1994

Yaqin, Ainul, Pendidikan Multikultural Cross-cultural Understanding untuk Demokrasi dan Keadilan, Yogyakarta: Pilar Media, 2005 
Zaprulkhan, Filsafat Ilmu Sebuah Analisis Kontemporer, Jakarta: Raja Grafindo, 2016

\section{Referensi Jurnal}

Muliadi, Erlan, Urgensi Pembelajaran Pendidikan Agama Islam Berbasis Multikultural di Sekolah, Ditulis dalam Jurnal Pendidikan Pendidikan Islam, Fakultas Tarbiyah dan Keguruan UIN Sunan Kalijaga Yogyakarta Volume I, Nomor 1, Juni 2012

Adhani, Yuli, Konsep Pendidikan Multikultural Sebagai Sarana Alternatif Pencegahan Konflik, Ditulis dalam Jurnal Sosio Didaktika: Vol. 1, No. 1 Mei 2014 